\title{
Optimization of Maize-Vegetable (African Eggplant and Pepper) Intercrops in Northern, Upper West and Upper East Regions of Ghana
}

\author{
Tignegre JBS ${ }^{1 *}$, LARBI $A^{2}$, Tenkouano $A^{1}$, Nurudeen $A^{2}$, Asante $M^{2}$, Boateng $R^{2}$, Rouamba $A^{1}$, Sobgui $M^{1}$, and \\ Chagomoka $\mathrm{T}^{1}$ \\ ${ }^{1}$ Department of World Vegetable Center, Samanko Research Station, Africa
}

${ }^{2}$ Department of Agriculture, International Institute for Tropical Agriculture, West Africa

Submission: February 01, 2018; Published: March 28, 2018

"Corresponding author: Tignegre JBS, World Vegetable Center, West and Central Africa, Samanko Research Station, BP 320 Bamako, Mali, Email: jean-baptiste.tignegre@worldveg.org

\begin{abstract}
Intercropping is an important practice in subsistence and food production farming systems in many developing countries. In the Guinea savanna of Northern Ghana, vegetable-maize intercropping with hot pepper, African eggplant and other vegetables is widely practiced during the humid season. Although this system is dominant, little is known regarding the optimal population densities and spatial arrangements for intercropped vegetables. Our objective was to determine the profitability of maize-vegetable intercropping as well as the biological yields resulting from various spatial arrangements and planting densities of intercrops. Trials were conducted during the rainy season from May to October of 2014 and 2015 in the Northern, Upper West and Upper East regions of Ghana. Each trial had eight treatments, including two pure stand options for each crop and four different vegetable-maize intercrops. The field layout was a randomized complete block design with three to four replications. Each farmer was assumed as a replication. Data collection included biological fruit or grain yields and estimation of land equivalent ratios (LER). LER values varied from one region to another and sometimes over years. Stable and beneficial spatial arrangements and planting densities were identified that can be recommended to farmers for intensification and scaling in both regions (UER and NR). For African eggplant, the optimal intercropping systems were 2 rows of maize at higher density: 1 row of African eggplant at recommended density, or 1 row of maize at recommended density: 1 row of African eggplant at recommended density. For pepper, the optimal intercropping system was 2 rows of maize at higher density: 1 row of pepper at the recommended density.
\end{abstract}

Keywords: Maize; African eggplant; Pepper; Intercrops; Sole crop; Land equivalent ratios; Productivity

Abbreviations : LER: Land Equivalent Ratio; RCBD: Randomized Complete Block Design; LSD: Least Significant Difference; ROC: Republic of China; DFID: Department for International Development; SARI: Savanna Agricultural Research Institute; ACIAR: Australian Centre for International Agricultural Research; USAID: United States Agency for International Development; IITA: International Institute for Tropical Agriculture

\section{Introduction}

Intercropping has survived the evolution of agriculture in the semiarid areas of the tropics. Farmers practice vegetable-maize intercropping as it ensures sustained production at reasonable levels with minimal risk to satisfy subsistence and commercial needs [1,2]. Food can be secured in times of crop failure; if one crop fails, there is another available for harvest [3]. Intercropping meets farmers' social and economic needs, and the development of improved intercrop farming systems can enhance productivity of small-scale farmers.

Intercropping is an important practice in subsistence and food production farming systems in many developing countries [4]. In the Guinea savanna of Northern Ghana, maize (Zea mays
L.) is one the most widely grown food staples for intercropping during the humid season. The components of maize intercrops include soybean [5,6] fruit crops and vegetables [7-9]. Okra, tomato, hot pepper, African eggplant and roselle are the major vegetables intercropped with maize in Ghana during the humid season.

Damages by insect pests and diseases are often higher under sole cropping than intercropping systems [10]. Populations of insects such as aphid and thrips are significantly reduced in cowpea-sorghum intercrops [11]. Pest and disease pressure are moderate in chili-maize [12] and tomato-maize [13]. The effect of intercropping on pests and diseases reduces the effort and inputs required for crop protection. 
Positive physiological interactions can sometimes be observed from intercropping. For example, interactive effects between population density and sorghum-soybean intercrops result in increases of soybean seed protein [14]. There may be a symbiotic cohabitation between the two crops where intercropping reduces soil erosion due to optimum coverage of the soil [15]. Negative interactions may also occur; sorghum variety CE145-66 had negative effects on groundnut intercrops due to the release of allelopathic phenolic compounds into the soil [16].

To ease adoption by farmers, an improved intercropping system needs to be more productive than traditional intercropping or mono cropping. Some authors suggested that a common unit could be used as a basis for the evaluation of the two components of an intercropped system [4]. A method was proposed for quantitative evaluation of the productivity of the intercropped species based on the intensity of land use, the production of constituents and the capital return [17]. Willey defined the land equivalent ratio (LER) as the total land area necessary under a monoculture cropping system to achieve yield performance similar to that obtained in a poly culture system. Ajeigbe et al. [18] used the land equivalent ratio to measure the economic income of the two practices in cereal-cowpea intercrops. If intercropping gross return/ha over the single crop gross return/ha is greater than one, then intercropping is more beneficial than a single crop. It was found that intercropping maize with beans showed higher yield advantage in terms of LER compared to a single crop [19]. However, for most cropping systems, the benefits of intercropping have yet to be optimized due to a lack of knowledge regarding spatial arrangements and planting densities. The objectives of our investigation were to

1) Assess the effects of spatial arrangements and planting densities of maize-vegetable intercrops on the production of both crop species, and

2) Determine the productivity of the vegetable-maize intercropping system in three administrative regions of Northern Ghana. The null hypothesis tested was maizeAfrican eggplant or maize-pepper intercrops and sole cropping of each component have equal benefits.

\section{Materials and Methods}

Trials were designed and conducted during the rainy season from May to October in 2014 and 2015 in the Northern, Upper West and Upper East savanna regions of Ghana. Each test or test farmer formed a single replicate of eight treatments. These treatments, which were combinations of spatial arrangements and planting density, were tested in the vegetable-maize intercropped trials with three replications.

Planting densities for maize and vegetables during 2014 and 2015 humid seasons in Ghana Treatments for spatial arrangements x planting density comprised
1) sole vegetable at the recommended planting density for the region,

2) sole maize at the recommended planting density $(67,000$ plants/ha) for the region,

3) sole vegetable at low planting density,

4) pure maize at high planting density $(133,000$ plants/ ha). Intercropped maize-vegetable treatments were 1 row of maize at the recommended planting density and 1 row of vegetable the recommended desinty,

5) 1 row of maize at the recommended planting density and 2 rows of vegetable at low planting density

6) 2 rows of maize at high planting density and 1 row of vegetable at the recommended planting density

7) 2 rows of maize at high planting density and 2 rows of vegetable at low planting density.

\section{Genetic materials}

Vegetables crops used in this study were African eggplant (Solanum aethiopicum L.) and hot pepper (Capsicum annum). Each farmer was considered as a replication and tested a set of eight treatments. 'Abontem' was the maize variety planted. The vegetable varieties were:

1) eggplant - 'Kotobi' and

2) pepper - 'Cayenne'.

Nurseries were set up in all intervention communities for growing pepper, eggplant and tomato seedlings. Dressed seeds for all crops were sown at a depth of 2-3 cm and mulched. Experimental plots in all intervention communities were ploughed and harrowed. A randomized complete block design (RCBD) with a plot size of $9 \mathrm{mx} 4 \mathrm{~m}$ was used. Each experiment had eight treatments and three or four replications. Basal compound fertilizer (15N:15P:15K) was applied to both maize and vegetables. Crops were top-dressed with sulphate of ammonia 5-6 weeks after planting. Plots were hand-weeded at 2 and 5 weeks after planting. Pesticides Lambda Super and Cymetox Super were applied to control insect pests. Data collected on maize and vegetables included grain and fresh fruit weight, respectively. The data collected on roselle included dry calyx weight.

\section{Statistical Analysis}

Genstat Edition 17th was used to compare treatments of spatial arrangements $x$ planting density. The land equivalent ratio (LER) was used to estimate how productive intercropping was compared to pure stand cultivation. The Least Significant Difference (LSD) test procedure in Genstat Edition 17th was used for mean yield separation at 95\% confidence interval.

LER $=[$ Maize intercropped*(Maize Pure stand $)-1]+[$ Vegetable Intercropped*(Vegetable Pure stand)-1] 
These values were obtained for a given intercropped system by using means for the region. A LER value greater than 1 indicated a synergistic interaction between intercropping components (beneficial intercrop) while a LER value less than 1 indicated an antagonistic interaction, in which case pure stand cultivation was more productive than intercropping.

\section{Results and Discussion}

\section{Optimized spatial arrangement $x$ planting density for African eggplant-maize intercrops in three regions of Ghana}

In UER, except for treatments of African eggplant in 2014 $(p=0.936)$, the results showed that the effects of treatments were significant for maize in $2014(\mathrm{p}=0.028)$ and $2015(\mathrm{p}=0.001)$ and African eggplant in 2015 ( $\mathrm{p}=0.001)$ (Table 1).

The treatment with 1 row of maize at recommended density and 2 rows of African eggplant at lower density was the highest yielding for maize $(15,194 \mathrm{~kg} / \mathrm{ha})$ in 2014 . In 2015 , sole maize and sole African eggplant yielded higher than intercropped. The LER was $>1$ for all treatments of African eggplant-maize intercrops in UER in 2014. The LER was $>1$ for 2 rows of maize at higher density: 1 row of African eggplant at recommended density (LER=1.18) and for 1 row of maize at recommended density: 1 row of African eggplant at recommended density (1.15) in UER in 2015. These two out-performing treatments did not differ much in LER values but they did differ in the increase of maize populations from 1 row of maize at recommended density to 2 rows of maize at higher density. For the two intercropped systems with same maize populations, one row of African eggplant at the recommended planting density may be cheaper than 2 rows of African eggplant at higher density in terms of seed cost, and also may be the most appropriate choice based on crop yield. As reported by Baker and Norman (1975) and Beets (1990) such beneficial intercropping systems ensure sustained production with minimal risk to satisfy subsistence and commercial needs for farmers.

In NR, the results showed that the effects of treatments were significant for African eggplant $(p=0.001)$ and maize $(p=0.001)$ in 2014 and African eggplant in $2015(\mathrm{p}=0.014)$ and African eggplant in 2015 ( $p=0.001)$ (Table 2). The effects of treatments were not significant for maize in $2015(\mathrm{p}=0.136)$. LER was $>1$ for all intercrops in 2014 and 2015 except for 2 rows of maize at higher density: 2 rows of African eggplant at lower density (Table 2). Across two years, LER values were consistently highest for 2 rows of African eggplant at low planting density and 1 row of maize at the recommended density. In 2014 and 2015, sole maize and sole African eggplant yielded higher than all intercrops. Similar negative interactions were reported on groundnut intercrops by [16] that could be due to the release of allelopathic phenolic compounds into the soil.

Table 1: Yields (kg/ha) and land equivalent ratios (LER) of African eggplant and maize in the intercropped farm fields under different planting densities in Upper East Region (UER) of Ghana during 2014 and 2015 humid seasons.

\begin{tabular}{|c|c|c|c|c|c|c|c|}
\hline \multirow[b]{2}{*}{ Plant density } & \multirow[b]{2}{*}{$\begin{array}{c}\text { Spatial } \\
\text { arrangement }\end{array}$} & \multicolumn{3}{|c|}{ UER 2014} & \multicolumn{3}{|c|}{ UER 2015} \\
\hline & & $\begin{array}{c}\text { African } \\
\text { eggplant }\end{array}$ & Maize & LER & $\begin{array}{c}\text { African } \\
\text { eggplant }\end{array}$ & Maize & LER \\
\hline Maize (67.000) & PSR1 & & 14806 & & & 2101 & \\
\hline Maize (133.000) & $\mathrm{PSH} 2$ & & 9014 & & & 2003 & \\
\hline Eggplant (28.000) & PSR1 & 1505 & & & 7298 & & \\
\hline Eggplant (18.500) & PSL3 & 1769 & & & 7558 & & \\
\hline Maize (67.000) + Eggplant (28.000) & 1MR4 : 1EPR5 & 1530 & 10586 & 2.19 & 4800 & 979 & 1.15 \\
\hline Maize (67.000) + Eggplant (18.500) & 1MR4 : 2EPL6 & 1535 & 15194 & 2.55 & 3894 & 594 & 0.81 \\
\hline Maize (133.000) + Eggplant (28.000) & 2MH7 : 1EPR5 & 1329 & 11194 & 1.64 & 2230 & 1830 & 1.18 \\
\hline Maize (133.000) + Eggplant (18.500) & 2MH7 : 2EPL5 & 1600 & 14722 & 1.9 & 2766 & 1124 & 0.9 \\
\hline LSD & & NS & $4119^{*}$ & & $1750.1^{* *}$ & $569.7^{* *}$ & \\
\hline
\end{tabular}

Table 2: Yields (kg/ha) and land equivalent ratios (LER) of eggplant and maize in the intercropped farm fields under different planting densities in the Northern (NR) Region of Ghana during 2014 and 2015 humid seasons.

\begin{tabular}{|c|c|c|c|c|c|c|c|}
\hline \multicolumn{2}{|c|}{} & \multicolumn{3}{|c|}{ NR 2014 } & \multicolumn{3}{c|}{ NR 2015 } \\
\hline Plant density & $\begin{array}{c}\text { Spatial } \\
\text { arrangement }\end{array}$ & $\begin{array}{c}\text { African } \\
\text { eggplant }\end{array}$ & Maize & LER & $\begin{array}{c}\text { African } \\
\text { eggplant }\end{array}$ & Maize & LER \\
\hline Maize (67.000) & PSR1 & & 1880 & & & 4528 & \\
\hline Maize (133.000) & PSH2 & & 1823 & & & 3644 & \\
\hline Eggplant (28.000) & PSR1 & 10665 & & & 5206 & & \\
\hline Eggplant (18.500) & PSL3 & 9124 & & & 3683 & & 1.69 \\
\hline Maize (67.000) + Eggplant (28.000) & 1MR4:1EPR5 & 3299 & 3020 & 1.97 & 2194 & 4622 & 2.08 \\
\hline
\end{tabular}


JOJ Horticulture \& Arboriculture

\begin{tabular}{|c|c|c|c|c|c|c|c|}
\hline Maize (67.000) + Eggplant (18.500) & 1MR4 : 2EPL6 & 2456 & 3145 & 1.99 & 3272 & 4350 & 1.37 \\
\hline Maize (133.000) + Eggplant (28.000) & 2MH7 : 1EPR5 & 3232 & 1744 & 1.23 & 1778 & 4667 & 1.53 \\
\hline Maize (133.000) + Eggplant (18.500) & 2MH7 : 2EPL5 & 3623 & 898 & 0.87 & 2350 & 4039 & \\
\hline $\begin{array}{c}\text { Mean separation test } \\
\text { (Tukey's test) }\end{array}$ & $516.5^{* *}$ & $779.2^{* *}$ & & $2150.3^{*}$ & NS & \\
\cline { 3 - 8 } & & & & & & \\
\hline
\end{tabular}

In conclusion, LER was consistently>1 in both regions (UER and NR) across two years (2014 and 2015) for 2 rows of maize at higher density: 1 row of African eggplant at recommended density and for 1 row of maize at recommended density: 1 row of African eggplant at recommended density. These two treatments are recommended in UER and NR for African eggplant-maize intercrops.

Optimized spatial arrangement $x$ planting density for pepper-maize intercrops in two regions of Ghana

In UER in 2015, the effects of pepper and maize treatments were significant with $\mathrm{p}=0.001$ and $\mathrm{p}=0.047$ respectively. Yield in pure stand cropping was higher than under intercropping (Table 3), except for 1 row of pepper at the recommended density: 1 row of maize at the recommended density. All other intercropped systems showed LER $>1$. The intercropped system, which involved 2 rows of maize at higher density: 1 row of pepper at the recommended density yielded $28 \%$ more than single cropping of each crop. Intercropping maize with pepper revealed higher yield advantage in terms of LER as compared to a single crop, which is similar to the results found by Tsubo et al. [19] on maize-bean intercrops.

In NR, the effects of treatments were significant for maize and pepper in 2014 and not significant in 2015 (Table 4). Sole crops showed higher yields than intercrops irrespective of the crop species. In 2014, LER was $>1$ for 1 row of maize at recommended density: 1 row of pepper at recommended density and for 2 rows of maize at higher density: 1 row of pepper at the recommended density. In 2015, LER was >1 for all intercrops. Gutierrez [12] reported that synergistic interactions for maizepepper intercrops could be partly explained by moderate pest and disease pressure in chili-maize intercropping system.

Table 3: Yields (kg/ha) and land equivalent ratios (LER) of pepper and maize in the intercropped farm fields under different planting densities in Upper East Region (UER) of Ghana in 2015 humid season.

\begin{tabular}{|c|c|c|c|c|}
\hline \multirow[b]{2}{*}{ Plant density } & \multirow[b]{2}{*}{ Spatial arrangement } & \multicolumn{3}{|c|}{ UER 2015} \\
\hline & & Pepper & Maize & LER \\
\hline Maize (67.000) & PSR1 & & 1151.7 & \\
\hline Maize (133.000) & PSH2 & & 1533.3 & \\
\hline Pepper (28.000) & PSR1 & 748.4 & & \\
\hline Pepper (18.500) & PSL3 & 500.3 & & \\
\hline Maize (67.000) + Pepper (28.000) & 1MR4 : 1RSR8 & 304.2 & 621.1 & 0.81 \\
\hline Maize (67.000) + Pepper (18.500) & 1MR4 : 2RSL9 & 297.9 & 683.4 & 1.04 \\
\hline Maize (133.000) + Pepper (28.000) & 2MH7 : 1RSR8 & 189.7 & 1182.3 & 1.28 \\
\hline Maize (133.000) + Pepper (18.500) & 2MH7 : 2RSL9 & 211.6 & 784.7 & 1.10 \\
\hline LSD & $114^{* *}$ & $607.6^{*}$ & & \\
\hline
\end{tabular}

Table 4: Yields (kg/ha) and land equivalent ratios (LER) of pepper and maize in the intercropped farm fields under different planting densities in the Northern Region (NR) of Ghana during 2014 and 2015 humid seasons.

\begin{tabular}{|c|c|c|c|c|c|c|c|}
\hline \multirow[b]{2}{*}{ Plant density } & \multirow[b]{2}{*}{ Spatial arrangement } & \multicolumn{3}{|c|}{ NR 2014} & \multicolumn{3}{|c|}{ NR 2015} \\
\hline & & Pepper & Maize & LER & Pepper & Maize & LER \\
\hline Maize $(67,000)$ & PSR1 & & 1688 & & & 3483 & \\
\hline Maize $(133,000)$ & PSH2 & & 1592 & & & 3400 & \\
\hline Pepper $(28,000)$ & PSR1 & 1377,8 & & & 700 & & \\
\hline Pepper $(18,500)$ & PSL3 & 1626 & & & 600 & & \\
\hline Maize $(67,000)+$ Pepper $(28,000)$ & 1MR4 : 1RSR8 & 905,2 & 638 & 1,06 & 527,8 & 2911 & 1,61 \\
\hline Maize $(67,000)+$ Pepper $(18,500)$ & 1MR4 : 2RSL9 & 674,1 & 703 & 0,86 & 477,8 & 3750 & 1,90 \\
\hline Maize $(133,000)+$ Pepper $(28,000)$ & 2MH7 : 1RSR8 & 467,1 & 1244 & 1,08 & 444,4 & 3794 & 1,72 \\
\hline Maize $(133,000)+$ Pepper $(18,500)$ & 2MH7 : 2RSL9 & 512,5 & 938 & 0,87 & 538,9 & 3428 & 1,88 \\
\hline LSD & $320^{* *}$ & $498^{* *}$ & & NS & NS & & \\
\hline
\end{tabular}


Growing 2 rows of maize at higher density: 1 row of pepper at the recommended density or 1 row of maize at recommended density: 1 rows of pepper at recommended density were more beneficial than growing a sole crop of pepper or maize. This result was consistent with LER $>1$ over two consecutive years (2014 and 2015) and all three regions investigated (UER and $\mathrm{NR}$ ), suggesting that this specific spatial arrangement $\mathrm{x}$ planting density can be recommended as an optimized pepper-maize intercropping practice for UER and NR.

\section{Conclusion}

Mixed cropping of vegetable and cereals are current practices in Sudan savanna zones of Ghana and West Africa. Studies were conducted in Northern Ghana in 2014 or 2015 with two vegetable crops (African eggplant and pepper) intercropped with maize using treatments combining different spatial arrangements and planting density.

Synergistic interactions were discovered for intensification of vegetable: maize production that showed more advantages than sole cropping or simple mixed cropping with no control of population density. Based on biological yields, the following spatial arrangements and planting densities can be recommended for more efficient crop production. With African eggplant, in both regions (UER and NR) across two years (2014 and 2015) the optimal intercropping system was 2 rows of maize at higher density: 1 row of African eggplant at recommended density, and for 1 row of maize at recommended density: 1 row of African eggplant at recommended density. With pepper, the optimal intercropping system was 2 rows of maize at higher density: 1 row of pepper at the recommended density. The above intercropping systems can be recommended for scaling and intensification in scaling out in Northern Ghana.

\section{Acknowledgment}

Funding for this research was provided by the United States Agency for International Development (USAID) and core donors to the World Vegetable Center: Republic of China (ROC), UK Department for International Development (DFID), United States Agency for International Development (USAID), Australian Centre for International Agricultural Research (ACIAR), Germany, Thailand, Philippines, Korea, and Japan.

The researchers are grateful to the Africa RISING Project, the United States Agency for International Development (USAID), the Savanna Agricultural Research Institute (SARI) and the International Institute for Tropical Agriculture (IITA) in Ghana for hosting the research trials and providing personnel, logistics and facilities for data collection. We would also like to thank the World Vegetable Center for providing personnel and project management assistance.

\section{References}

1. Baker EFI, Norman DW (1975) Cropping systems in Northern Nigeria, In: Harwood, RR (Eds,). Proceedings of the cropping systems workshop held at the International Rice Research Institute, Loss Banos, Lagoons, Philippines, USA 18-20; 334-361.

2. Beets WC (1990) Raising and sustaining productivity of smallholder farming systems in the tropics. Alkmaar, Holland: Ag Bé Publishing Pp. 754.

3. Lawson IYD, Issahaku A, Acheampong SK, Adams B, Tuffour V (2013) Time of planting and weed suppression abilities of some legumes intercropped with maize in the Guinea savanna zone of Ghana. Agriculture and Biology Journal of North America 4(4): 358-363.

4. Tsubo M, Walker S, Ogindo HOA (2005) Simulation model of cereallegume intercropping systems for semi-arid regions. I. Model application. Field Crop Research 93(1): 23-33.

5. Muoneke CO, Ogwuche MO, Kalu BA (2007) Effect of maize planting density on the performance of maize/soybean intercropping system in a Guinea savanna agro ecosystem 2(12): 667-677.

6. Hugar HY and Palled YB (2008) Effect of Intercropped Vegetables on Maize and Associated Weeds in Maize-Vegetable Intercropping Systems. Karnataka Journal of Agric. Sci 21(2): 159-161.

7. Ouama G and Jeruto $P$ (2010) Sustainable horticultural crop production through intercropping: The case of fruits and vegetable crops 1: 10981105.

8. Seran TH and Brintha I (2010) Review on Maize Based Intercropping. Journal of Agronomy 9: 135-145.

9. Ijoyah MO, Iorlamen T and Idoko GA (2012) Yield response of intercropped maize (Zea Mais L.) and okra (Abelmoschus esculentus (L.) Moench) to seasonal conditions at Makurdi in Nigeria. Journal of Natural Sciences Research 2(6): 79-86.

10. Trenbath BR (1993) Intercropping for the management of pests and diseases. Field Crop Res 34(3-4): 381-405.

11. Nampala P, Ogenga-Latigo MW, Kyamanywa S, Adipala E, Oyobo N, et al. (2002) Potential impact of intercropping on major cowpea field pests in Uganda. African Crop Science Journal 10(4): 335-344.

12.Gutierrez C (1999) Evaluation of maize-chilli intercrop for the management of Anthonomus eugenii in Nicaragua. Manejo Integrado de Plagas 54:73-77.

13. Pino M, De-Los A, Domini ME, Terry E, Bertoli M, et al. (1993) Maize as a protective crop for tomato in conditions of environmental stress. Cultivos Tropicales 15: 60-63.

14. Akunda EMW (2001) Crop yields of Sorghum and soybeans in an intercrop. The Journal of Food Technology in Africa 6(1): 2-4.

15.Zougmoré R, Kambou NF, Ouattara K, Guillobez S (2001) Sorghumcowpea intercropping: an effective technique against runoff and soil erosion in the Sahel (Saria, Burkina Faso). Arid Soil Research and Rehabilitation. 14(4): 329-342.

16. Sene M, Gallet C and Doré T (2001) Phenolic compounds in a Sahelian sorghum (Sorghum bicolor) genotype (ce (145-166)) and associated soils. Journal of Chemical Ecology 27: 81-92.

17. Willey RW (1985) Evaluation and presentation of intercropping advantages. Experimental Agriculture 21(2): 119-133.

18. Ajeigbe HA, Singh BB, Oseni TO (2005) Cowpea-cereal intercrop productivity in the Sudan savanna zone of Nigeria as affected by planting pattern, crop variety, and pest management. African Crop Science Journal 13(4): 269-279.

19. Tsubo M, Ogindo HO, Walker S (2004) Yield evaluation of maizebean intercropping in a semi arid region of South Africa. African Crop Science 12(4): 351-358. 
This work is licensed under Creative Commons Attribution 4.0 License DOI: 10.19080/JOJHA.2018.01.555557

\section{Your next submission with Juniper Publishers} will reach you the below assets

- Quality Editorial service

- Swift Peer Review

- Reprints availability

- E-prints Service

- Manuscript Podcast for convenient understanding

- Global attainment for your research

- Manuscript accessibility in different formats

( Pdf, E-pub, Full Text, Audio)

- Unceasing customer service

Track the below URL for one-step submission https://juniperpublishers.com/online-submission.php 